\title{
PENGARUH PENAMBAHAN SARI BUAH SIRSAK TERHADAP SIFAT SENSORIS MINUMAN ISOTONIK AIR KELAPA (Cocos nucifera $\mathrm{L.}$.)
}

\author{
The Effect of Soursop Juice Concentration on Sensory Properties of Coconut (Cocos \\ nucifera L.) Isotonic Drink
}

Wulan Kristie Lempoy $^{1)^{*}}$, Lucia C. Mandey ${ }^{2)}$, dan Jenny E. A. Kandou ${ }^{2)}$

${ }^{1)}$ Mahasiswa Program Studi Teknologi Pangan

${ }^{2)}$ Dosen Program Studi Teknologi Pangan

Jurusan Teknologi Pertanian Fakultas Pertanian Universitas Sam Ratulangi

Jl. Kampus UNSRAT Manado, 95115

*Email: (wklempoy@gmail.com)

\begin{abstract}
This study aims to determine the proportion addition of soursop juice and analyze the chemical contents of isotonic drink from mature coconut water (Cocos nucifera L.) This research was conducted by adding $100 \mathrm{ml}, 200 \mathrm{ml}$, and $300 \mathrm{ml}$ of soursop juice to $1000 \mathrm{ml}$ of coconut water. The test parameters were organoleptic tests using hedonic methods including flavor, taste, and turbidity. The best treatment was followed by chemical testing including sodium, potassium, acidity $(\mathrm{pH})$, total acid and total sugar. The result of organoleptic test showed that $1000 \mathrm{ml}$ of coconut water without soursop juice addition has a value of 2,73 (neutral), while the addition of $100 \mathrm{ml}$ soursop juice has a value of 3,43 (neutral), the addition of $200 \mathrm{ml}$ soursop juice has a value of 3,54 (like), and the addition of 300 $\mathrm{ml}$ soursoup juice has a value of 3,71 (like). In conclusion, the best result is the addition of $300 \mathrm{ml}$ soursop that had a mineral content of sodium as much as $469,36 \mathrm{mg} / \mathrm{kg}$, potassium as much as $2014,45 \mathrm{mg} / \mathrm{kg}$, $\mathrm{pH} 4,65$, total acid $0,54 \%$ and total sugar $6,33 \%$.
\end{abstract}

Keywords: Isotonic Drinks, Soursop Juice, Coconut Water

\section{PENDAHULUAN}

Tanaman kelapa (Cocos nucifera L.) merupakan tanaman yang banyak terdapat di Sulawesi Utara. Data Direktorat Jenderal Perkebunan tahun 2016-2017 luas perkebunan kelapa Sulawesi Utara adalah sebesar 221,709 ha sampai 222,370 ha dengan total produksi 265,637 ton sampai 268,882 ton. Tanaman kelapa biasa disebut dengan The Tree of Life. Hal ini dikarenakan semua bagian dari tanaman kelapa dapat dimanfaatkan, mulai dari akar, batang, daun, buah, hingga air dari buah kelapa. Air Kelapa merupakan cairan yang terdapat secara alami pada bagian dalam buah kelapa (Prades dkk., 2011).

Buah kelapa rata-rata memiliki 230$300 \mathrm{ml}$ air kelapa (Wahyuni., 2018). Air 
kelapa sering disebut sebagai minuman isotonik alami karena mempunyai komposisi mineral $\mathrm{Na}$ dan $\mathrm{K}$ yang baik untuk tubuh. Penelitian sebelumnya (Tih dkk., 2016) tentang konsumsi air kelapa sebelum dan selama olahraga lari membuktikan air kelapa lebih efektif untuk menjaga kebugaran serta ketahanan tubuh dibandingkan dengan air mineral, air gula dan minuman isotonik pada lakilaki dewasa bukan atlet. Air kelapa terbagi atas air dari buah kelapa muda dan tua. Berbeda dengan air kelapa muda pemanfaatan air kepala tua di Sulawesi Utara belum optimal dan hanya diolah menjadi produk ata de coco sehingga banyak air kelapa tua terbuang dan menimbulkan efek negatif. Menurut Arsa dkk., (2011) Air kelapa tua memiliki komposisi mineral yang tidak kalah dari air kelapa muda yaitu natrium sebanyak $510 \mathrm{mg} / \mathrm{kg}$ dan kalium sebanyak 3469,6 $\mathrm{mg} / \mathrm{kg}$. Sehingga untuk mengoptimalkan pemanfaatan air kelapa tua yang terbuang, maka dapat diolah menjadi minuman isotonik.

Minuman isotonik adalah minuman ringan yang mengandung mineral natrium dan kalium (Badan standarisasi nasional., 1998). Minuman isotonik atau sport drink berfungsi untuk mempertahankan cairan dan garam tubuh serta memberikan energi ketika melakukan aktivitas. Komponen utama dari minuman isotonik adalah air sebagai pengganti cairan tubuh, mineral sebagai pengganti elektrolit tubuh yang hilang dan penambahan flavor seperti perisa buah sehingga dapat diterima oleh konsumen (Koswara., 2009). Penelitian sebelumnya (Setyadjit dkk., 2014) tentang formulasi minuman isotonik membuktikan panelis menyukai isotonik yang memiliki rasa sedikit manis dan agak asam. Kandungan gula yang rendah pada air kelapa tua sebesar 3\% (Rindengan., 2007) menyebabkan air kelapa tua memiliki rasa yang hambar dan kurang disukai, sehingga untuk meningkatkan rasa air kelapa tua maka perlu adanya penambahan flavor yang memiliki rasa khas yang tajam seperti sari buah sirsak.

Buah sirsak (Anonna muricata L.) terdiri dari 76,5\% daging, 20\% kulit, 8,5\% biji dan $4 \%$ jantung buah (Sihombing., 2012). Buah sirsak memiliki kandungan gula sebesar 11,7\% (Dhianawaty., 2012), asam malat dan asam sitrat sehingga menyebabkan buah sirsak memiliki rasa yang asam dan manis, selain itu buah sirsak juga memiliki aroma yang khas serta diperkaya dengan kandungan gizi seperti natrium, kalium, klorida, lemak, protein dan karbohidrat (Badrie dkk., 2010). Oleh karena itu buah sirsak cukup potensial untuk ditambahkan dalam minuman isotonik air kelapa yang memiliki tingkat kematangan tua.

Berdasarkan uraian diatas maka dilakukan penelitian pemanfaatan air kelapa tua dengan penambahan sari buah sirsak untuk memperbaiki cita rasa dari air kelapa tua yang hambar pada minuman isotonik.

\section{METODE PENELTIAN}

\section{Tempat dan Waktu}

Penelitian ini di laksanakan di Laboratorium Teknologi Pangan Fakultas Pertanian Universitas Sam Ratulangi Manado dan Laboratorium Baristand Manado pada bulan April - Oktober tahun 2019.

\section{Bahan dan Alat}

Bahan yang digunakan untuk membuat isotonik antara lain air kelapa yang diambil dari perkebunan Balit Palma Manado, dengan tingkat kematangan tua berumur 11 bulan yang memiliki ciri-ciri penampakan sabut mulai mengering dan bila buah dikocok berbunyi karena air kelapa sudah mengurang, buah sirsak yang diambil dari perkebunan Tondano, dengan tingkat kematangan matang optimal ditandai dengan kulit berwarna hijau kekuningan, bila disentuh buah 
terasa lunak, duri pada buah tidak tajam dan tangkai buah menguning dan sukrosa serta air mineral, sedangkan bahan yang digunakan untuk pengujian kimia adalah asam nitrat, asam sulfat, larutan luff schoorl, phenolphthalein, dan akuades.

Alat yang digunakan untuk pembuatan isotonik antara lain timbangan analitik, wadah, botol kaca, penjepit botol, gelas ukur, kain saring dan blender, sedangkan alat yang digunakan untuk pengujian antara lain, kertas saringan, microwave digester, spektofotometer serapan atom, $\mathrm{pH}$ meter, pendingin tegak dan kuisioner.

\section{Rancangan Penelitian}

Penelitian dilakukan menggunakan rancangan acak lengkap (RAL) dengan campuran air kelapa yang memiliki tingkat kematangan tua dan sari buah sirsak, menghasilkan 4 perlakuan yang berbeda dengan proporsi sebagai berikut
A. $1000 \mathrm{ml}$ Air kelapa tanpa penambahan sari buah sirsak
B. $1000 \mathrm{ml}$ Air kelapa $+100 \mathrm{ml}$ sari buah sirsak
C. $1000 \mathrm{ml}$ Air kelapa $+200 \mathrm{ml}$ sari buah sirsak
D. $1000 \mathrm{ml}$ Air kelapa $+300 \mathrm{ml}$ sari buah sirsak

Masing-masing perlakuan dilakukan ulangan sebanyak 3 kali sehingga diperoleh 12 sampel.

\section{Prosedur Pengolahan Isotonik}

Proses pembuatan isotonik dilakukan dengan metode Langkong dkk., (2018) yang telah dimodifikasi, dimulai dengan pembuatan sari buah sirsak. Buah sirsak yang matang sempurna dibersihkan dimana daging buah sirsak dipisahkan dari kulit, tangkai dan biji. Daging buah yang sudah dibersihkan kemudian dihancurkan menggunakan blender dengan penambahan air 1:1 dan disaring menggunakan kain saring. Kemudian dilanjutkan dengan proses pengambilan air kelapa dimana air kelapa dipisahkan dari batok dan daging kelapa kemudian air kelapa disaring untuk mengeluarkan serabut atau kotoran yang terikut dalam air kelapa sebelum dimasukkan dalam wadah. Setelah semua bahan siap, sari buah sirsak dan air kelapa diukur sesuai dengan perlakuan dan masing-masing perlakuan ditambahkan gula sebanyak 5\% kemudian dihomogenkan dalam botol dan setiap perlakuan dipasteurisasi menggunakan suhu $63^{\circ} \mathrm{C}$ selama 30 menit.

\section{Parameter Pengujian}

Pengujian yang akan diamati pada penelitian ini adalah pengujian sensoris meliputi rasa, aroma, kekeruhan dan analisis kimia meliputi mineral natrium dan mineral kalium, derajat keasaman $(\mathrm{pH})$, total asam serta total gula.

\section{Prosedur Analisis Pengujian Sifat Sensoris}

Tingkat penerimaan dengan skala hedonik merupakan metode yang dilakukan dalam pengujian organoleptik ini oleh Susiwi., (2009). Uji sensoris menggunakan panelis agak terlatih yang terdiri dari 25 orang dengan memberikan penilaian secara pribadi terhadap sampel yang disajikan. Uji sensoris dilakukan untuk mengetahui tingkat kesukaan panelis terhadap minuman isotonik air kelapa dengan penambahan sari buah sirsak. Parameter yang harus diuji panelis meliputi rasa, aroma dan kekeruhan dengan memberikan penilaian skala 1-5, dimana 1 = sangat tidak suka, $2=$ tidak suka, $3=$ biasa, $4=$ suka dan $5=$ sangat suka

\section{Analisis Mineral Natrium dan Kalium}

nalisis mineral dilakukan dengan metode spektrofotometri BSN.,(1998). Persiapan Sampel dimulai dengan menimbang 0,8 gram sampel. Pengujian dimulai dengan proses destruksi basah dimana sampel ditambahkan $10 \mathrm{ml}$ asam 
nitrat dan dimasukkan kedalam microwave digester. Sampel hasil destruksi kemudian dimasukkan dalam labu takar $100 \mathrm{ml}$ dan ditambahkan akuades hingga batas garis, sampel kemudian diukur absorbansinya dengan menggunakan spektrofotometer serapan atom. Kadar natrium dan kalium dihitung dengan rumus:

Kadar Mineral $=\frac{\text { Absorbansi } x \text { Volume }(\mathrm{ml})}{\text { Berat Sampel }(\mathrm{g})}$

\section{Analisis Derajat Keasaman (pH)}

Analisis derajat keasaman $(\mathrm{pH})$ dilakukan dengan metode SNI 01-28911992 (BSN., 1992) menggunakan $\mathrm{pH}$ meter dimulai dengan persiapan sampel dimana sampel diletakkan dalam beaker gelas kemudian dilanjutkan dengan kalibrasi $\mathrm{pH}$ meter dengan larutan buffer standar hal ini dilakukan setiap saat akan melakukan pengujian. Setelah kalibrasi kemudian elektroda dibersihkan dengan cara mencelupkan elektroda pada akuades, pembersihan dilakukan setiap akan menganti sampel pengujian. Elektroda yang telah bersih kemudian dicelupkan ke dalam sampel yang akan diuji. Nilai $\mathrm{pH}$ akan terlihat pada skala $\mathrm{pH}$ meter yang ditunjukan.

\section{Pengujian Total Asam}

Analisis total asam dilakukan dengan metode SNI 01-3546-2004 (BSN., 2004) diawali dengan menimbang sebanyak 10$15 \mathrm{~g}$ sampel dan dimasukkan kedalam labu ukur $250 \mathrm{ml}$ kemudian ditambahkan akuades sampai tanda garis kemudian kocok dan saring. Sampel kemudia dipipet sebanyak $100 \mathrm{ml}$ dan ditambahkan 3 tetes indikator PP $0,1 \%$. Pengujian dilanjutkan dengan mentitrasi sampel dengan $\mathrm{NaOH}$ $0,1 \%$ sampai berubah warna. Total Asam dihitung dengan rumus:

$$
\% \text { keasamaan }=\frac{\mathrm{V} \times \mathrm{N} \times \mathrm{B} \times \mathrm{Fp}}{\mathrm{W}} \times 100 \%
$$

Keterangan

$\mathrm{V}=$ Larutan $\mathrm{NaOH}$ yang digunakan (ml)

$\mathrm{N}=$ Normalitas larutan $\mathrm{NaOH} 0,1 \mathrm{~N}$

$\mathrm{B}=$ Bobot setara asam asetat

$\mathrm{Fp}=$ Faktor pengencer

$\mathrm{W}=$ Bobot contoh $(\mathrm{mg})$

\section{Pengujian Total Gula}

Analisis total gula dilakukan dengan metode SNI 3544:2013 (BSN., 2013). Pengujian total gula diawali dengan menimbang $2 \mathrm{~g}$ sampel dan menambahkan akuades kemudian dimasukkan ke dalam labu ukur $250 \mathrm{ml}$. Sampel kemudian ditambahkan $\mathrm{Pb}$ asetat $5 \mathrm{ml}$ dan $\mathrm{NH}_{4} 20$ $\mathrm{ml}$ sampai timbul endapan, setelah itu sampel ditambahkan akuades sampai tanda garis dan didigoyang, tunggu selama 30 menit dan disaring dengan kertas saring. Pengujian dilanjutkan dengan memipet $50 \mathrm{ml}$ sampel dan dimasukkan dalam gelas ukur $100 \mathrm{ml}$ kemudian ditambahakan $\mathrm{HCl} 25 \%$ sebanyak $10 \mathrm{ml}$ setelah itu dimasukkan kedalam air panas selama 10 menit, kemudia sampel ditambahkan $\mathrm{NaOH} \quad 30 \%$ sampai berwarna merah jambu dan dilanjutkan dengan penambahan akuades sampai tanda garis pada labu takar dan sampel didinginkan sampai mencapai suhu ruang. Setelah mencapai suhu ruang sampel dipipet sebanyak $5 \mathrm{ml}$ dan ditambahkan larutan luff schoorl sebanyak $25 \mathrm{ml}$ dan akuades $20 \mathrm{ml}$, kemudian sampel dimasukkan kedalam pendingin tegak dan dipanaskan selama 20 menit setelah itu sampel didinginkan. Setelah sampel dingin tambahkan $10 \mathrm{ml} \mathrm{KI}, 25 \mathrm{ml} \mathrm{H}_{2} \mathrm{SO}_{4}$ dan kanji sampai sampel berubah warna kemudian sampel dititrasi dengan larutan tio $0,1 \mathrm{~N}$ sampai berubah warna. Total gula dihitung dengan rumus :

$$
\% \text { gula }=\frac{\mathrm{W} 1 \times \mathrm{fp}}{\mathrm{W}} \times 100 \%
$$

\section{Keterangan :}


$\mathrm{W} 1=$ Volum titar blanko - volum titar contoh (ml)

$\mathrm{p}=$ Faktor Pengencer

$\mathrm{W}=$ Bobot contoh $(\mathrm{mg})$

\section{HASIL DAN PEMBAHASAN}

\section{Sifat Sensoris:}

Rasa

Hasil pengamatan tingkat kesukaan terhadap rasa minuman isotonik berbahan baku air kelapa tua dengan penambahan sari buah sirsak adalah tidak suka sampai suka dengan nilai berkisar antara 2,45 sampai 3,92 dapat dilihat pada Tabel 1.

Hasil analisis sidik ragam terhadap rasa minuman isotonik menunjukan nilai $\mathrm{F}$ hitung lebih besar dari nilai $\mathrm{F}$ tabel sehingga dilanjutkan dengan uji BNT dan mendapatkan hasil perlakuan A $(1000 \mathrm{ml}$ air kelapa tanpa penambahan sari buah sirsak) berbeda nyata dengan perlakuan B $(1000 \mathrm{ml}$ air kelapa $+100 \mathrm{ml}$ sari buah sirsak), C (1000 ml air kelapa $+200 \mathrm{ml}$ sari buah sirsak) dan D (1000 ml air kelapa $+300 \mathrm{ml}$ sari buah sirsak).

Pada Tabel 4 nilai tertinggi kesukaan panelis terhadap rasa minuman isotonik diperoleh pada perlakuan D $(1000 \mathrm{ml}$ air kelapa $+300 \mathrm{ml}$ sari buah sirsak) dan perlakuan C (1000 ml air kelapa $+200 \mathrm{ml}$ sari buah sirsak) dengan nilai 3,92 dan 3,57 (suka). Panelis menyukai perlakuan $\mathrm{D}$ dan $\mathrm{C}$ karena memiliki rasa asam, hal ini akibat dari campuran sari buah sirsak yang mempunyai kandungan asam malat dan asam sitrat (Silalahi., 2014). Sehingga semakin tinggi proporsi buah sirsak yang ditambahkan dalam minuman isotonik akan memberikan rasa asam yang disukai panelis. Hal ini juga didukung oleh Setyadjit dkk., (2014) yang menyatakan panelis lebih menyukai minuman isotonik yang memiliki rasa yang sedikit manis dan agak asam. Sedangkan pada perlakuan B $(1000 \mathrm{ml}$ air kelapa $+100 \mathrm{ml}$ sari buah sirsak) mendapatkan nilai 3,35 (netral) hal ini disebabkan karena campuran sari buah sirsak sedikit sehingga menghasilkan rasa asam yang kurang. Nilai terendah diperoleh pada perlakuan A (1000 ml air kelapa tua tanpa penambahan sari buah sirsak) yaitu 2,45 (tidak suka) hal ini karena pada perlakuan A tidak ditambahkan sari buah sirsak sehingga rasa hambar dari air kelapa tua dapat terasa dan menyebabkan panelis tidak suka.

\section{Aroma}

Hasil pengamatan tingkat kesukaan terhadap aroma minuman isotonik berbahan baku air kelapa dengan penambahan sari buah sirsak adalah tidak suka sampai suka dengan nilai berkisar antara 2,48 sampai 3,67 dapat dilihat pada Tabel 2.

Hasil analisis sidik ragam terhadap aroma minuman isotonik menunjukan nilai $\mathrm{F}$ hitung lebih besar dari nilai $\mathrm{F}$ tabel sehingga dilanjutkan dengan uji BNT dan mendapatkan hasil perlakuan B $(1000 \mathrm{ml}$ air kelapa $+100 \mathrm{ml}$ sari buah sirsak), $\mathrm{C}$ (1000 ml air kelapa + $200 \mathrm{ml}$ sari buah sirsak) dan D (1000 ml air kelapa + 300 $\mathrm{ml}$ sari buah sirsak) berbeda tidak nyata.

Tabel 1. Nilai Rata-rata Kesukaan Rasa Isotonik Air Kelapa dan Sari Buah Sirsak

\begin{tabular}{cccc}
\hline Sampel & Perlakuan & Kekeruhan & Kriteria \\
\hline A & $1000 \mathrm{ml}$ air kelapa tanpa sari buah sirsak & $2,45^{a}$ & Tidak suka \\
B & $1000 \mathrm{ml}$ air kelapa + 100 ml sari buah sirsak & $3,35^{b}$ & Netral \\
C & $1000 \mathrm{ml}$ air kelapa + 200 ml sari buah sirsak & $3,57^{b c}$ & Suka \\
D & $1000 \mathrm{ml}$ air kelapa + 300 ml sari buah sirsak & $3,92^{c}$ & Suka \\
\hline
\end{tabular}


BNT $5 \%=0,48(*)$ Notasi yang berbeda menunjukan adanya perbedaan nyata

Tabel 2. Nilai Rata-rata Kesukaan Aroma Isotonik Air Kelapa dan Sari Buah Sirsak

\begin{tabular}{cccc}
\hline Sampel & Perlakuan & Kekeruhan & Kriteria \\
\hline A & $1000 \mathrm{ml}$ air kelapa tanpa sari buah sirsak & $2,48^{a}$ & Tidak suka \\
B & $1000 \mathrm{ml}$ air kelapa $+100 \mathrm{ml}$ sari buah sirsak & $3,09^{b}$ & Netral \\
C & $1000 \mathrm{ml}$ air kelapa $+200 \mathrm{ml}$ sari buah sirsak & $3,33^{b}$ & Netral \\
D & $1000 \mathrm{ml}$ air kelapa $+300 \mathrm{ml}$ sari buah sirsak & $3,67^{b}$ & Suka \\
\hline
\end{tabular}

BNT $5 \%=0,48(*)$ Notasi yang berbeda menunjukan adanya perbedaan nyata

Ketiga perlakuan ini berbeda nyata dengan perlakuan A (1000 ml air kelapa tua tanpa pembahan sari buah sirsak).

Pada Tabel 2 nilai tertinggi kesukaan panelis terhadap aroma diperoleh pada perlakuan D (1000 ml air kelapa $+300 \mathrm{ml}$ sari buah sirsak) yaitu 3,67 (Suka). Perlakuan D menghasilkan aroma yang disukai panelis karena mempunyai aroma khas buah sirsak yang kuat hal ini diduga karena senyawa volatil dari buah sirsak yang menguap akibat pemanasan. Proses pemanasan dapat menguapkan sejumlah senyawa volatil yang bertanggung jawab atas timbulnya aroma (Susanto., 2011). Pada perlakuan D konsentrasi sari buah sirsak yang ditambahkan paling banyak sehingga disukai panelis, semakin banyak sari buah sirsak ditambahkan akan semakin menutupi aroma dari air kelapa dan menghasilkan aroma minuman isotonik yang disukai. Nilai terendah diperoleh pada pada perlakuan A $(1000 \mathrm{ml}$ air kelapa tanpa penambahan sari buah sirsak) yaitu 2,48 (tidak suka) hal ini karena pada perlakuan A tidak ditambahkan sari buah sirsak sehingga menghasilkan minuman isotonik yang masih memiliki aroma khas air kelapa tua yang tidak disukai panelis.

\section{Kekeruhan}

Hasil pengamatan tingkat kesukaan terhadap kekeruhan minuman isotonik air kelapa dengan penambahan sari buah sirsak adalah netral sampai suka dengan nilai berkisar antara 3,25 (netral) sampai 3,84 (suka) dapat dilihat pada Tabel 3.

Hasil analisis sidik ragam terhadap kekeruhan minuman isotonik (Lampiran 5) menunjukan nilai $F$ hitung lebih kecil dari nilai $F$ tabel sehingga tingkat kesukaan panelis terhadap kekeruhan minuman isotonik air kelapa dengan penambahan sari buah sirsak tidak berbeda nyata atau tidak berpengaruh. Pada Tabel 3 nilai tertinggi kesukaan panelis terhadap kekeruhan diperoleh pada perlakuan B $(1000 \mathrm{ml}$ air kelapa $+100 \mathrm{ml}$ sari buah sirsak) yaitu 3,84 (suka) sedangkan nilai terendah pada perlakuan A (1000 ml air kelapa tanpa penambahan sari buah sirsak) yaitu 3,25 (netral).

Tabel 3. Nilai Rata-rata Kesukaan Kekeruhan Isotonik Air Kelapa dan Sari Buah Sirsak

\begin{tabular}{cccc}
\hline Sampel & Perlakuan & Kekeruhan & Kriteria \\
\hline A & $1000 \mathrm{ml}$ air kelapa tanpa sari buah sirsak & 3,25 & Netral \\
B & $1000 \mathrm{ml}$ air kelapa + 100 ml sari buah sirsak & 3,84 & Suka \\
C & $1000 \mathrm{ml}$ air kelapa + 200 ml sari buah sirsak & 3,71 & Suka \\
D & $1000 \mathrm{ml}$ air kelapa + 300 ml sari buah sirsak & 3,53 & Suka \\
\hline
\end{tabular}


Air kelapa sebagai bahan baku yang digunakan dalam pembuatan minuman isotonik adalah air kelapa dengan tingkat kematangan tua yang memiliki kenampakan air yang keruh hal ini dipengaruhi oleh umur air kelapa. Kenampakan fisik air kelapa yang semakin tua akan cenderung keruh (Arsa., 2011). Namun tingkat kekeruhan air kelapa diduga masih kurang disukai panelis hal ini terbukti dengan rendahnya nilai uji tingkat kesukaan terhadap kekeruhan minuman istonik pada perlakuan A (1000 ml air kelapa tua tanpa penambahan sari buah sirsak). Panelis lebih menyukai tingkat kekeruhan minuman isotonik dengan penambahan sari buah sirsak pada perlakuan B (1000 $\mathrm{ml}$ air kelapa tua $+100 \mathrm{ml}$ sari buah sirsak).

Kekeruhan dalam minuman isotonik dengan penambahan sari buah sirsak diduga akibat sifat fisik dari air kelapa tua yang keruh dan buah sirsak yang memiliki kenampakan daging berwarna putih dan berserat seperti kapas (Sihombing., 2012).
Semakin banyak penambahan sari buah sirsak akan menghasilkan minuman isotonik yang semakin keruh oleh sebab itu pada perlakuan C (1000 ml air kelapa tua $+200 \mathrm{ml}$ sari buah sirsak) dan perlakuan $\mathrm{D}(1000 \mathrm{ml}$ air kelapa tua +300 ml sari buah sirsak) minuman isotonik yang dihasilkan menjadi terlalu keruh sehingga tidak disukai oleh panelis.

\section{Uji Sensoris Keseluruhan}

Secara keseluruhan tingkat kesukaan panelis terhadap isotonik air kelapa dengan penambahan sari buah sirsak terhadap rasa, aroma dan kekeruhan dapat dilihat pada Tabel 4 dan Gambar 1. Perlakuan yang memiliki radar yang paling luas dan seimbang antara rasa, aroma, kekeruhan dan memiliki rata-rata tertinggi adalah perlakuan D $(1000 \mathrm{ml}$ air kelapa $+300 \mathrm{ml}$ sari buah sirsak) dengan nilai rata 3,71 (suka).

Tabel 4. Nilai Rata-rata Tingkat Kesukaan Secara Keseluruhan

\begin{tabular}{ccccc}
\hline Sampel & Rasa & Aroma & Kekeruhan & Rata-rata \\
\hline A & 2,45 & 2,48 & 3,25 & 2,73 \\
B & 3,35 & 3,09 & 3,84 & 3,43 \\
C & 3,57 & 3,33 & 3,71 & 3,54 \\
D & 3,92 & 3,67 & 3,53 & 3,71 \\
\hline
\end{tabular}
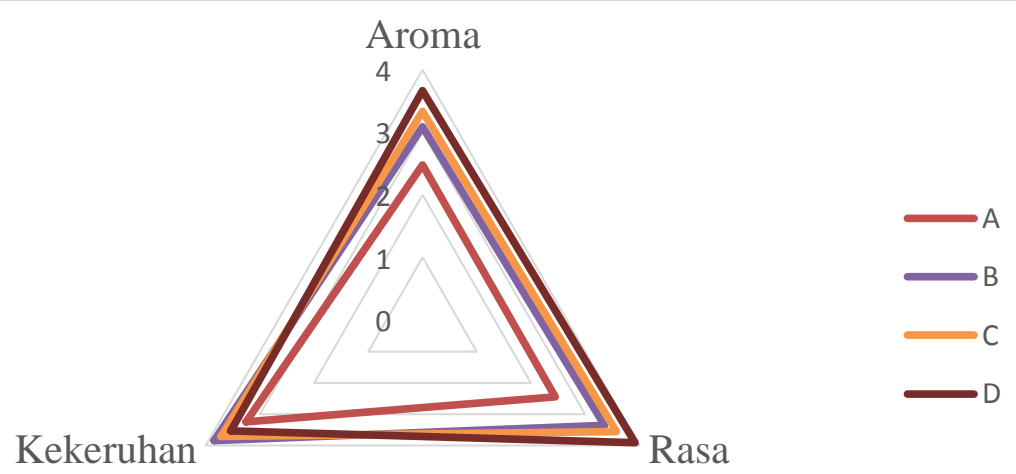

Gambar 1. Tingkat Penerimaan Secara Keseluruhan 


\section{Analisis Kimia}

Analisis kimia dilakukan pada D (1000 ml air kelapa $+300 \mathrm{ml}$ saru buah sirsak) sebagai perlakuan yang paling disukai oleh panelis. Nilai rata-rata analisis kimia isotonik air kelapa dan sari buah sirsak pada perlakuan D (1000 ml air kelapa $+300 \mathrm{ml}$ sari buah sirsak) dapat dilihat pada Tabel 5.

\section{Mineral Natrium}

Pada Tabel 5 Konsentrasi mineral natrium yang dihasilkan isotonik air kelapa dengan penambahan $300 \mathrm{ml}$ sari buah sirsak adalah $469,36 \mathrm{mg} / \mathrm{kg}$ atau setara dengan $20,42 \mathrm{mEq} / \mathrm{L}$. Isotonik yang dihasilkan akibat pencampuran air kelapa dan sari buah sirsak sudah memenuhi standar SNI 01-4452-1998 tentang minuman isotonik yaitu kurang dari $800-$ $1000 \mathrm{mg} / \mathrm{kg}$ hal ini dikarenakan bahan baku minuman isotonik yaitu air kelapa sudah memiliki jumlah mineral natrium yang sesuai dengan standar minuman isotonik yaitu berkisar antara $270 \mathrm{mg} / \mathrm{kg}$ sampai $593 \mathrm{mg} / \mathrm{kg}$ (Runtunuwu dkk., 2010). Hal ini didukung juga oleh Koswara., (2009) yang mencatat konsentrasi mineral natrium yang harus ada dalam minuman isotonik yaitu berkisar antara $20-80 \mathrm{mEq} / \mathrm{L}$ yang didasarkan pada penggantian natrium yang hilang dalam tubuh melalui keringat ketika beraktivitas.

\section{Mineral Kalium}

Pada Tabel 5 Konsentrasi mineral kalium yang dihasilkan isotonik air kelapa dengan penambahan sari buah sirsak 300 $\mathrm{ml}$ adalah sebesar $2014,45 \mathrm{mg} / \mathrm{kg}$ atau $51,53 \mathrm{mEq} / \mathrm{L}$. Yaswir., (2012) mencatat jumlah mineral kalium yang keluar dari dalam tubuh selama 24 jam adalah $40-80$ $\mathrm{mEq} / \mathrm{L}$. Hal ini membuktikan bahwa minuman isotonik yang dihasilkan mampu mengganti mineral kalium yang hilang hal ini disebabkan karena bahan baku air kelapa yang memang memiliki nilai kalium yang tinggi yaitu berkisar antara $2333 \mathrm{mg} / \mathrm{kg}$ atau 59,68 $\mathrm{mEq} / \mathrm{L}$ sampai $2857 \mathrm{mg} / \mathrm{kg}$ atau 73,09 $\mathrm{mEq} / \mathrm{L}$ (Runtunuwu dkk., 2010). Hal ini didukung juga dengan penelitian Tih dkk., (2016) yang mencatat mengkonsumsi air kelapa sebanyak $300 \mathrm{ml}$ sebelum dan selama latihan dengan jarak tempuh 400 meter dapat meningkatkan ketahanan berolahraga.

\section{Derajat Keasaman (pH)}

Pada Tabel 5 derajat keasaman (pH) isotonik air kelapa tua dengan penambahan $300 \mathrm{ml}$ sari buah sirsak adalah 4,65. Derajat keasaman minuman isotonik yang dihasilkan melebih SNI 014452-1998 tentang minuman isotonik. Keasaman minuman isotonik yang dihasilkan diduga akibat dari penambahan sari buah sirsak yang memiliki derajat keasaman rendah yaitu sebesar 3,7 (Badrie dkk., 2010). Menurut Rindengan., (2007) air kelapa tua memiliki derajat keasaman sebesar 5,5 kandungan $\mathrm{pH}$ rendah pada sari buah sirsak diduga dapat mempengaruhi kandungan $\mathrm{pH}$ pada air kelapa pada saat penambahan sehingga menyebabkan minuman isotonik yang dihasilkan memiliki $\mathrm{pH}$ yang rendah. Derajat keasaman $(\mathrm{pH})$ dapat mempengaruhi rasa dari isotonik yang dihasilkan. Hal ini berbanding lurus dengan tanggapan panelis yang menyebutkan isotonik yang pada sampel D (1000 ml air kelapa $+300 \mathrm{ml}$ sari buah sirsak) memilik rasa yang asam.

\section{Total Asam}

Pada Tabel 8 total asam yang terkandung dalam minuman isotonik air kelapa dengan penambahan $300 \mathrm{ml}$ sari buah sirsak memiliki nilai rata-rata $0,54 \%$. Pengujian total asam berhubungan dengan kandungan asam yang terdapat dalam suatu bahan pangan. Menurut Badrie dkk., (2010) kandungan asam yang dimiliki sirsak adalah asam malat dan asam sitrat. 
Tabel 5. Hasil Analisis Kimia Isotonik Air Kelapa Dengan Penambahan 300 ml Sari Buah Sirsak

\begin{tabular}{|l|l|l|l|}
\hline No. & Parameter & Satuan & Rata-rata \\
\hline 1 & Mineral Natrium & $\mathrm{mg} / \mathrm{kg}$ & 469,36 \\
\hline 2 & Mineral Kalium & $\mathrm{mg} / \mathrm{kg}$ & 2014,45 \\
\hline 3 & Tingkat Keasaman $(\mathrm{pH})$ & - & 4,65 \\
\hline 4 & Total Asam & $\%$ & 0,54 \\
\hline 5 & Total Gula & $\%$ & 6,33 \\
\hline
\end{tabular}

Total asam berhubungan dengan derajat keasaaman $(\mathrm{pH})$, semakin rendah total asam akan menunjukan $\mathrm{pH}$ yang meningkat begitu juga sebaliknya $\mathrm{pH}$ yang rendah akan menunjukan jumlah total asam yang tinggi (Maitimu dkk., 2013).

\section{Total Gula}

Pada Tabel 8 total gula yang dihasilkan isotonik air kelapa dengan penambahan $300 \mathrm{ml}$ sari buah sirsak memiliki rata-rata $6,33 \%$. Total gula yang dihasilkan minuman isotonik air kelapa dengan penambahan sari buah sirsak melebihi SNI 01-4452-1998 tentang minuman isotonik yaitu minimal $5 \%$. Menurut Rindengan., (2007) air kelapa tua memiliki kandungan gula sebesar 3\% peningkatan total gula yang dihasilkan dalam isotonik air kelapa akibat dari penambahan sari buah sirsak yang memiliki kandungan gula sebesar 11,7\% (Dhianawaty., 2012).

\section{KESIMPULAN}

Dari hasil penelitian disimpulkan bahwa penambahan sari buah sirsak pada minuman isotonik air kelapa yang disukai panelis berdasarkan uji sensoris secara keseluruhan adalah proporsi $1000 \mathrm{ml}$ air kelapa ditambahkan $300 \mathrm{ml}$ sari buah sirsak yang memiliki kandungan mineral natrium sebanyak $469,36 \mathrm{mg} / \mathrm{kg}$, mineral kalium sebanyak 2014,45 mg/kg, pH 4,65, total asam $0,54 \%$ dan total gula $6,33 \%$.

\section{DAFTAR PUSTAKA}

Arsa, M. 2011. Kandungan Natrium dan Kalium Larutan Isotonik Alami Air Kelapa (Cocos nucifera L) Varietas Eburnia, Viridis dan Hibrida. Program Pascasarjana Universitas Udayana, Denpasar.

Badan Standarisasi Nasional. 2004. SNI 01-3546-2004. Sirup. Badan Standarisasi Nasional, Jakarta.

Badan Standarisasi Nasional. 2013. SNI 01-3546-2004. Saus Tomat. Badan Standarisasi Nasional, Jakarta

Badan Standarisasi Nasional. 1992. SNI 01-2891-1992. Cara Uji Makanan dan Minuman. Badan Standarisasi Nasional, Jakarta.

Badan Standarisasi Nasional. 1998. SNI 01-4452-1998. Minuman Isotonik. Badan Standarisasi Nasional, Jakarta.

Badrie, N dan A. G. Schauss. 2010. Soursoup (Annona muricata L.) Composition, Nutritional Value, Medicanal Usesand Toxicology. Department of Food Production, Faculty of Science and Agriculture, University of the West Indies.

Dhianawaty, D. 2012. Perbandingan Kadar Glukosa Dalam Jus Buah Annona muricata (Sirsak) dan Averrhoa bilimbing (Belimbing Wuluh). Fakultas Kedokteran Universitas Padjajaran. Bandung 
Direktorat Jendral Perkebunan. 2016. Statistik Perkebunan Indonesia Komoditas Kelapa 2015-2017. Sekertariat Direktorat Jendral Perkebunan kementrian Pertanian.

Koswara, S. 2009. Minuman Isotonik. Ebookpangan.com.

tekpan.unimus.ac.id/wpcontent/uploads/2013/07/minuman -isotonik.pdf. diakses 28 Desember 2018

Langkong, J., N.K. Sukendar dan Z. Ihsan. 2018. Studi Pembuatan Minuman Isotonik Berbahan Baku Air Kelapa Tua (Cocos Nucifera l) dan Eksrtak Belimbing Wuluh (Avverhoa Bilimbi l) menggunakan metode sterilisasi Non-Thermal Selama Penyimpanan. Program Studi Ilmu dan Teknologi Pangan Departemen Teknologi Pertanian Universitas Hasanudin. Makassar.

Maitimu, C.V., A.M. Legowo dan A.N. Al-Baarri. 2013. Karakteristik Mikrobiologis, Kimia, Fisik dan Organoleptik Susu Pasteurisasi Dengan Penambahan Ekstrak Daun Aileru (Wrightia calycina) Selama Penyimpanan. Jurnal Aplikasi Teknologi Pangan Vol. 2 No. 1.

Prades, A., M. Dorinier., N. Diop dan J. Pain. 2012. Coconut Water Uses, Composition and Properties. EDP Sciences. Fruits,2012, Vol. 67.

Rindengan, B., S. Karouw., J. Towaha dan R. Hutapea. 2007. Pengaruh Perbandingan Air Kelapa dan Penambahan Daging Kelapa Muda Serta Lama Penyimpanan Terhadap Serbuk Minuman Kelapa. Balai Penelitian Tanaman Kelapa dan Palma Lain (Balitka) Mando. Jurnal LITTRI Vol. 12 No. 12.
Runtunuwu, S.D., J. Assa., D. Rawung dan W. Kumolontang. 2010. Kandungan Kimia Daging dan Air Buah Sepuluh Tetua Kelapa Dalam Komposit. Buletin Palma. Vol.12 No.1.

Setyadjit., E. Sukasih dan Sunarmani. 2014. Formulation Of Isotonic Drink Processed From Rambutan Fruit (Nephelium lappaceum L) cv. Lebak Bulus. Indonesian Center For Agricultural Postharvest Research and Development

Sihombing, I.V. 2012. Pengaruh Lama Penyimpanan Terhadap Kadar Vitamin C Dari Buah Sirsak (Annona Murricata L). Departemen Kimia Fakultas Matematia dan Ilmu Pengetahuan Alam Universitas Sumatra Utara. Medan.

Silalahi, R.C., I. Suhaidi dan L.N. Limbong. 2014. Pengaruh Perbandingan Sari Buah Sirsak Dengan Markisa dan Konsentrasi Gum Arab Terhadap Mutu Sorbet Air Kelapa. Program Studi Teknologi pangan Fakultas Pertanian Universitas Sumatra Utara. Medan. Vol.2 No.2.

Susiwi, S., 2009. Penilaian Organoleptik. Jurusan Pendidikan Kimia FPMIPA Universitas Pendidikan Indonesia.

Susanto, W.H dan B.R. Setyohadi. 2011. Pengaruh Varietas Apel (Malus sylvestris) dan Lama Fermentasi Oleh Khamir (Saccharomyces cerivisiae) Sebagai Perlakuan PraPengolahan Terhadap Karakteristik Sirup. Jurnal Teknologi Pertanian. Vol 12 (3): 135-142.

Tih, F., H. Pramono., S.T. Hasianna., E.T. Naryanto., A.G. Haryano dan O. Rachman. 2016. Efek Konsumsi Air Kelapa (Cocos Nucifera) 
Terhadap Ketahanan Berolahraga

Selam Latihan Lari pada Laki-laki

Dewasa Bukan Atlit. Fakultas

Kedokteran Universitas Kristen

Maranatha. Bandung.

Wahyuni, S. 2018. Pemanfaatan Limbah

Air Kelapa (Cocos nucifera L.)

Untuk Pembuatan Kecap dan Uji

Sensoris Sebagai Referensi Mata
Kuliah Bioteknologi. Fakultas Tarbiyah dan Keguruan Universitas Islam Negeri Ar-Ranir Darussalem. Banda Aceh.

Yaswir, R dan I. Ferawati. 2012. Fisiologi dan Gangguan Keseimbangan Natrium, Kalium dan Klorida serta Pemeriksaam Laboratorium. Jurnal Kesehatan Andala 